\title{
Torsional comparative biomechanical test of modified tibial-plateau-leveling osteotomy plate and locking plate in canine synthetic tíbias
}

\author{
[Teste de torção biomecânica comparative de placa de TPLO modificada e placa bloqueada \\ em tibia sintética canina] \\ G. Sembenelli ${ }^{1}$, A.C. Shimano ${ }^{3}$, M.C.N. Wittmaack ${ }^{1}$, T.A.S.S. Rocha ${ }^{1}$, P.C. Moraes ${ }^{2}$, \\ B.W. Minto $^{2}$, L.G.G.G. Dias $^{2 *}$ \\ ${ }^{1}$ Programa de pós-graduação - Universidade Estadual Paulista - Jaboticabal, SP \\ ${ }^{2}$ Universidade Estadual Paulista - Jaboticabal, SP \\ ${ }^{3}$ Universidade de São Paulo - Ribeirão Preto, SP
}

\begin{abstract}
The objective of this study was to develop a locked tibial-plateau-leveling osteotomy (TPLO) plate and to compare this implant with the conventional bone fixation method using a locked plate to determine bone stabilization against torsion forces. Maximum force, angle at peak torque, and stiffness values were determined. Ten synthetic tibias were used, divided into 2 groups. The results in Group 1 (modified TPLO plate) and Group 2 (locked plate) were assessed using analysis of variance and the means were compared using Tukey's test at $5 \%$ probability. There were significant differences in the angle at peak torque and stiffness. The group Modified TPLO plate had higher mean values of stiffness compared with Group locked plate. Group locked plate showed a greater angle at peak torque compared with Group modified TPLO plate. All constructs failed due to tibial fractures distal to the plate. The modified TPLO plate presented higher stiffness indexes than conventional locked plate in torsion. The locked plate presented greater elasticity than modified TPLO plate having greater angle at the peak of torque.
\end{abstract}

Keywords: orthopedics, osteosynthesis, biomechanics

\section{RESUMO}

O objetivo do presente estudo foi desenvolver placa de TPLO bloqueada modificada e avaliar, em ensaio de torção, a estabilização óssea proporcionada pelo implante desenvolvido comparativamente a método de fixação óssea convencional com placa reta bloqueada. As variáveis obtidas foram força máxima, ângulo no pico de torque e rigidez. Foram utilizadas 10 tíbias sintéticas, dividas em dois grupos. Os resultados obtidos do grupo 1 (placa TPLO modificada) e do grupo 2 (placa bloqueada) foram submetidos à análise de variância, e as médias comparadas entre si pelo teste de Tukey a $5 \%$ de probabilidade. Houve diferença significativa em relação às variáveis, ângulo no pico de torque e rigidez. Na variável rigidez, a média do grupo placa de TPLO modificada foi maior que a do grupo placa reta bloqueada. Em relação à variável ângulo no pico de torque, o grupo placa reta bloqueada foi superior ao grupo placa de TPLO modificada. Todas as montagens falharam devido à quebra do corpo de prova distal à placa. Conclui-se que a placa de TPLO modificada apresentou maior índice de rigidez que a placa reta convencional sob força de torção. A placa reta bloqueada apresentou maior ângulo no pico de torque, sendo, portando, mais elástica.

Palavras-chave: ortopedia, osteossíntese, biomecânica

\section{INTRODUCTION}

Comminuted fractures are biologically and biomechanically challenging. Non-sharing of

Recebido em 19 de dezembro de 2017

Aceito em 24 de janeiro de 2019

*Autor para correspondência (corresponding author)

E-mail: gustavogosuen@gmail.com forces with the bone column causes transfer to the implant throughout the consolidation period, thus requiring robust stabilization, generally using plate-rod constructs. Comminuted proximal fractures provide limited bone substrates, and few implant options can be used in these types of fractures. The number of screws 
per fragment is also reduced by the length of the proximal fragment (Koch, 2005; Hulse, 2014). Thus, the preservation of the fracture focus is impossible due to its proximity to the proximal fragment (Pozzi and Lewis, 2009).

The distal and proximal segments of long bones are exposed to greater stress from torsion forces than the middle diaphyseal segment due to the proximity of the joint, which exerts significant force in the case of the proximal tibia (Markel et al., 1994). Thus, we assumed that a modified TPLO plate might offer favorable biomechanical characteristics for proximal fractures with poor bone stock, because of the triangular arrangement of screws. Locked TPLO plates have more proximal holes than conventional locked plates, allowing adequate fixation of very small proximal fragments; however, they were not developed to reach distal portions of the tibia, making it impossible to treat comminuted diaphyseal fractures with small proximal fragments (Slocum and Slocum, 1993).

The modified TPLO plate can be used in a minimally invasive procedure by allowing insertion of a larger number of screws in the proximal fragment through a small incision. According to Ronga et al. (2009) this type of procedure is indicated for tibial fractures due to limited availability of soft tissue and vascularization, thus reducing the chance of injury to important structures. If plates are carefully implanted to minimize damage to soft tissues required for repair, in particular the blood vessels that extend to the periosteum from the muscles and fascia, the bone repair process is optimized (Mckibbin, 1978).

\section{MATERIALS AND METHOD}

The study used 10 synthetic right tibias (Nacional Ossos, São Paulo, Brazil) made from rigid polyurethane, based on a tibia from a Siberian husky dog. The synthetic canine tibias were made with support blocks at the distal and proximal ends. Implantation near the specimen ends prevents attachment to mechanical testing machines unless metallic implants (plates) are also used. Thus, extensions were created at the distal and proximal ends of the tibia to enable the attachment of a mechanical testing machine to the bearing blocks (Figure 1). The tibias were developed through a collaboration between the manufacturer and the Laboratory of Bioengineering, Department of Biomechanics, Medicine, and Rehabilitation of Locomotor Apparatus of the Faculty of Medicine of Ribeirão Preto/USP.

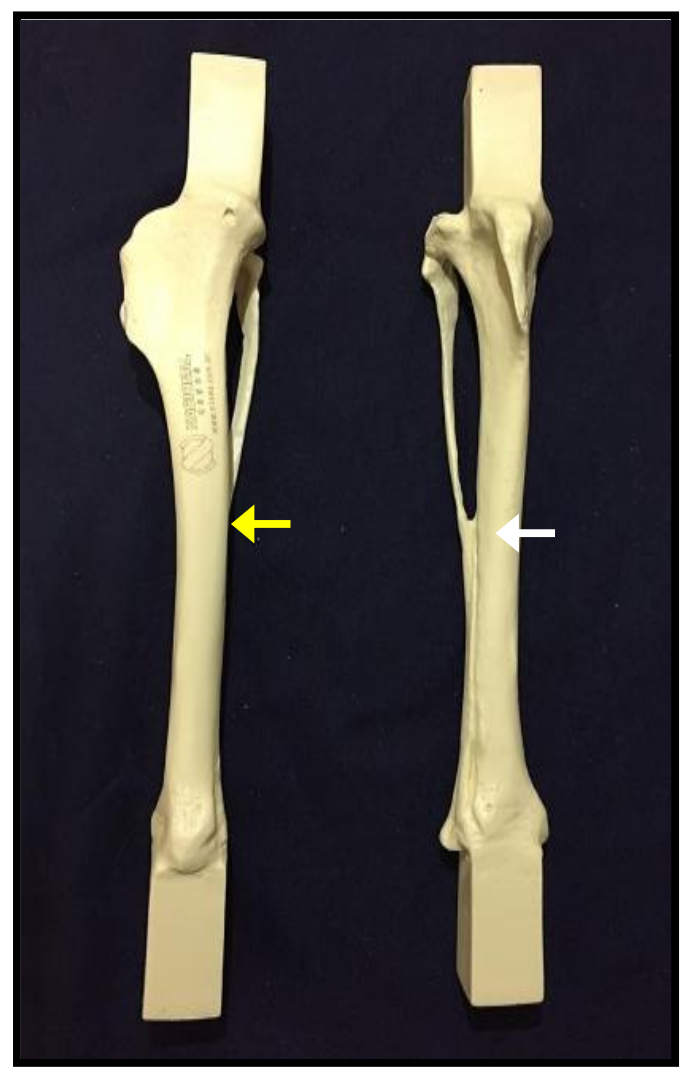

Figure 1. Mediolateral (yellow arrow) and craniocaudal (white arrow) views of right polyurethane canine synthetic tibias with support blocks at the distal and proximal ends developed to perform the torsion test.

A standardized $20 \mathrm{~mm}$ gap was created with two transverse cuts in the synthetic tibia to simulate a proximal comminuted fracture. The first cut was made $50 \mathrm{~mm}$ from the tibial plateau and the second at $70 \mathrm{~mm}$. The constructs were compared. A plate (Cão Médica, Campinas/SP) measuring $3.5 \mathrm{~mm} \times 11 \mathrm{~mm} \times 137 \mathrm{~mm}$ was developed for Group 1. Its proximal portion was similar to that of the TPLO plate. The proximal width was greater than that of the rest of the plate, with 3 holes that allowed the use of locked screws with different angulations. The proximal portion of the plate was modeled after the proximal medial aspect of the tibial epiphysis, enabling anatomical seating without the need for 
intraoperative shaping. The plate had 13 holes for locked screws of $3.5 \mathrm{~mm}$ in diameter, including the 3 screws in the proximal segment (Figure 2).

Group 2 used a $3.5 \mathrm{~mm}$ system with a $13.7 \mathrm{~cm}$, 11-hole plate. The distance between the hole centers was $12 \mathrm{~mm}$ in both plates (Figure 2). The 10 constructs $(5$ modified TPLO plates and 5 conventional plates) were created by a single investigator and the sequence of implantation was standardized for both groups. Three locked screws were used in the proximal fragment and 3 in the distal fragment in both groups (Figure 2b). Figure 3 shows the final appearance of the 10 specimens used in the torsion test after implantation. For the torsion test, the distal specimen block was secured to the machine and the proximal bearing block was internally rotated. A load cell with a capacity of $50 \mathrm{kgf}$ was used (Figure 4 ). The speed of the test was $0.4 \mathrm{rpm}$ (144 ø/min).

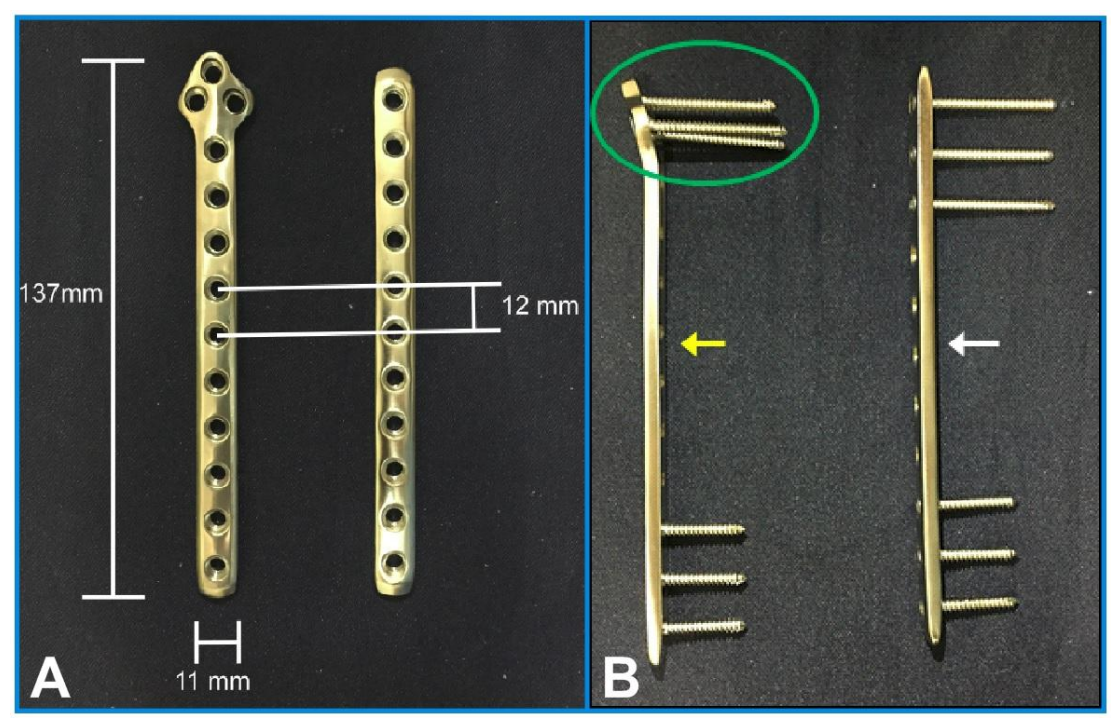

Figure 2. Front (Figure 2A) and side views of the modified TPLO and conventional plates which were compared in the torsion test. In Figure $2 \mathrm{a}$, the plate measures $137 \mathrm{~mm}$ in length and $11 \mathrm{~mm}$ wide. The distance between the hole centers is $12 \mathrm{~mm}$. Figure 2B. Side views of the modified TPLO (yellow arrow) and conventional plates (white arrow). Note the angulation of the proximal portion of the modified TPLO plate (green oval) as well as the angulation of the locked screws.

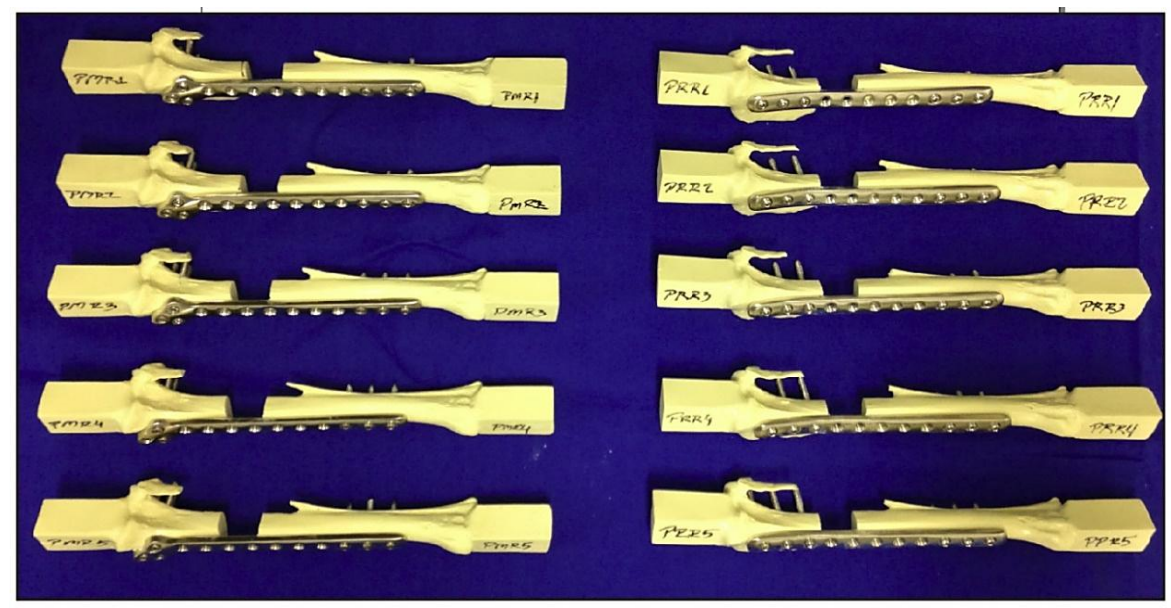

Figure 3. Final aspect of the 10 specimens used in the torsion test. Left: 5 constructions of the modified TPLO plate. Rigth: 5 constructions of the conventional plate. Note the standardized positioning of the implants and the locations of the gaps. 


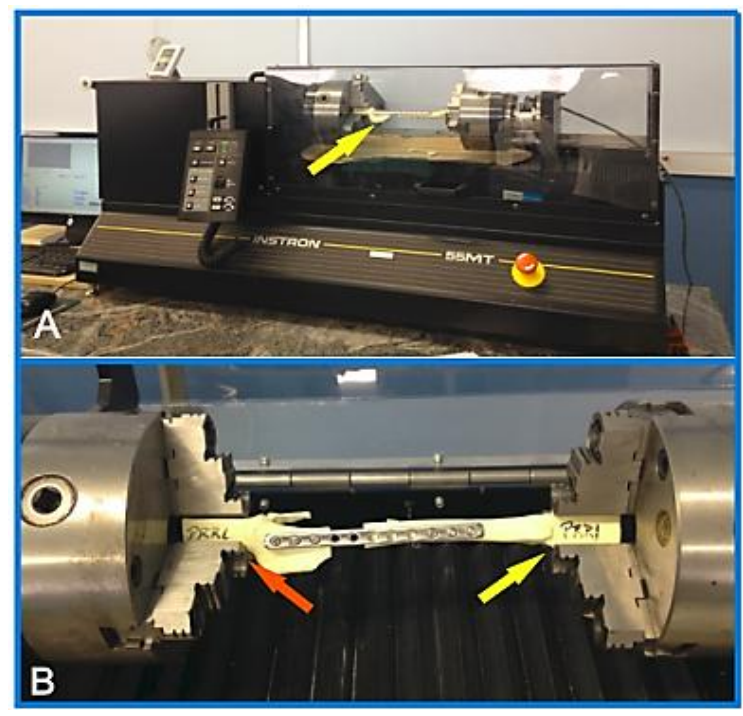

Figure 4. Photograph of the torsion test. A. Machine used in the torsion test with the construct in position. B. Test body attached to test machine. Yellow arrow: distal block of synthetic tibia attached to the fixed head of the machine. Red arrow: proximal block of synthetic tibia attached to the rotating head of the machine.

\section{RESULTS}

The angle and stiffness were measured at peak torque and the means and standard deviation for each group were calculated (Table 1). The peak torque results did not differ statistically between the three groups. There were significant differences between the groups in the average angles and stiffness at peak torque. In Table 1, averages followed by the same letter showed no significant differences.

Figures 4 and 5 show the respective forcedeflection curves of Groups 1 and 2. Failure of the constructs in both groups occurred due to fractures in the region of the most distal screw at the tibial isthmus (Figure 6).

Table 1. Mean values and standard deviation (SD) of variables in the torsion test

\begin{tabular}{lccc} 
& Group 1 (modified & Group 2 (straight plate) & P value \\
& TPLO) $($ Mean \pm SD) & (Mean \pm SD) & 0.56 \\
\hline Peak torque $(\mathrm{N} . \mathrm{m})$ & $1.04 \mathrm{a} \pm 0.56$ & $1.31 \mathrm{a} \pm 0.91$ & 0.0006 \\
Angle at peak torque (degrees) & $51.61 \mathrm{~b} \pm 5.22$ & $72.74 \mathrm{a} \pm 10.64$ & 0.0045 \\
Stiffiness $\left(\mathrm{N} . \mathrm{m} /{ }^{\circ}\right)$ & $0.4218 \mathrm{a}$ & $0.2873 \mathrm{~b}$ & \\
\hline
\end{tabular}

Averages followed by the same letter showed no significant differences.

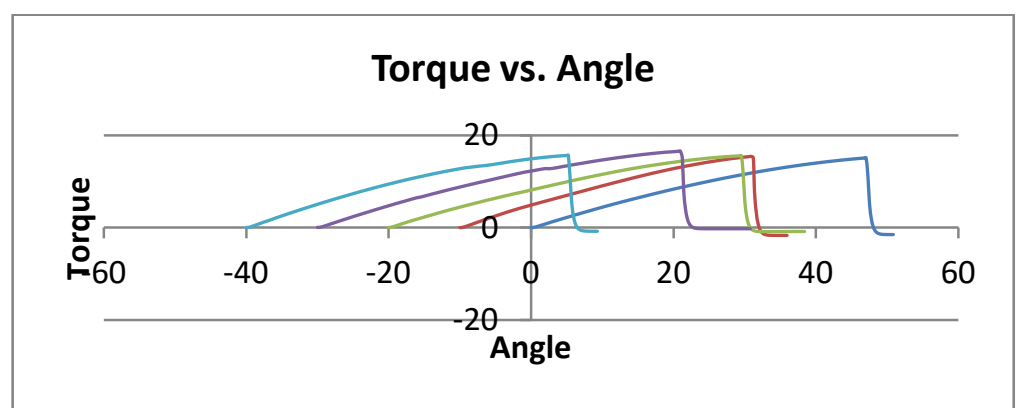

Figure 4. Force-deflection curves of the five repeats for the static torsion test of the modified TPLO plate (Group 1). 


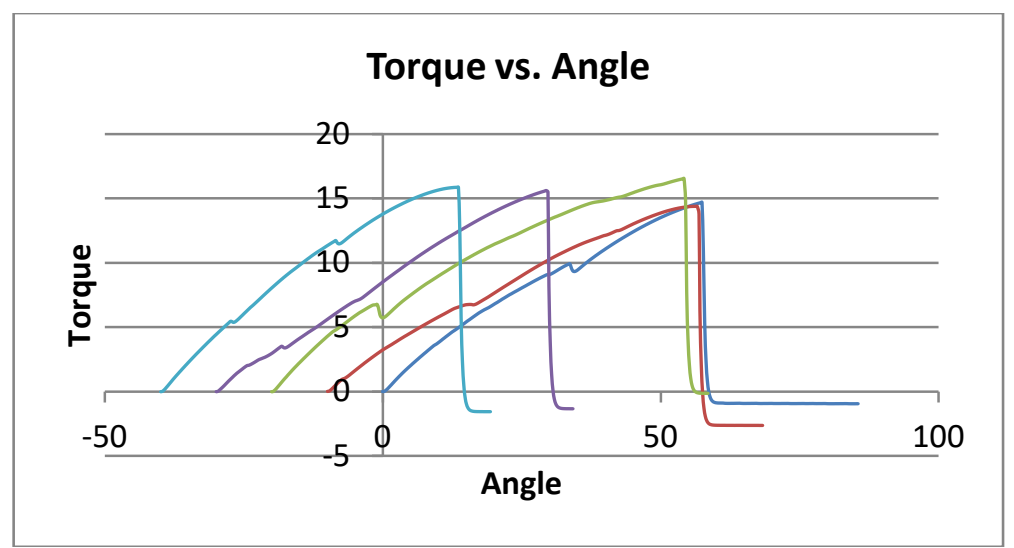

Figure 5. Force-deflection curves of the five repeats for the static torsion test of the conventional plate (Group 2).

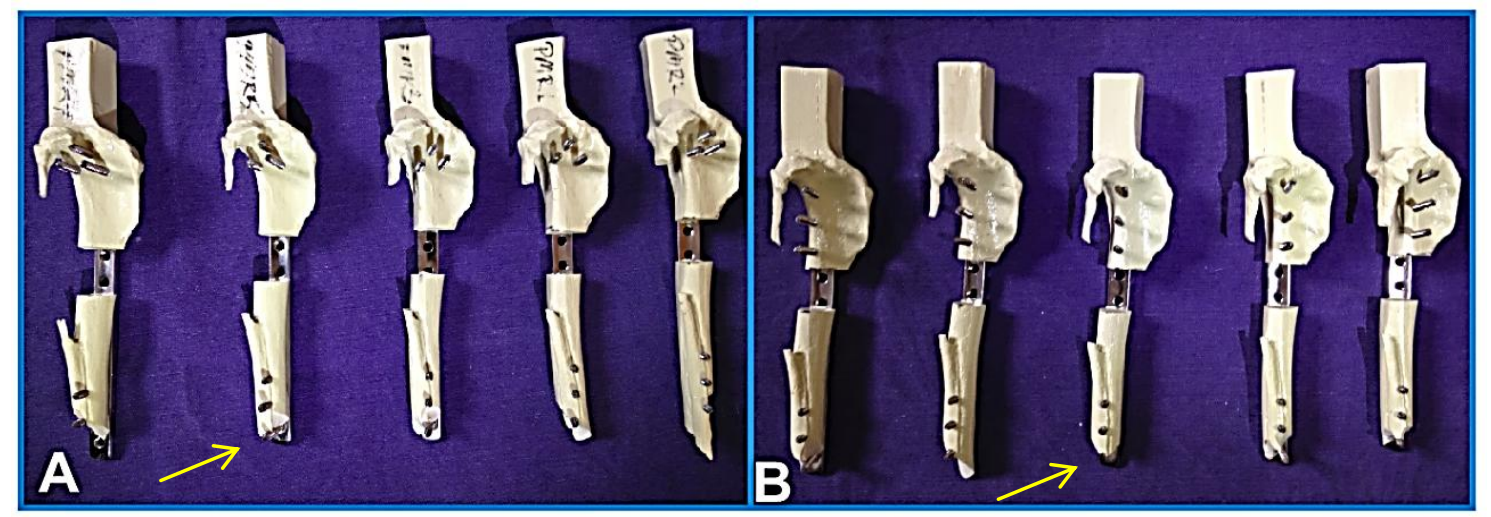

Figure 6. A and B: Photographs of lateral aspect of the constructions of Groups 1 and 2, respectively, after torsion testing. Yellow arrows: tibial fractures in the region of the most distal screw in all specimens.

\section{DISCUSSION}

The authors believe that the greater stiffness in Group 1 was due to triangular screw placement in the modified TPLO plate, which conferred greater stability on the proximal fragment. These data corroborate the known mechanical advantages of plates with non-aligned holes (Bordelon et al., 2009). These are called "broad" plates, and the hole non-alignment makes the construct multiplanar, thus providing stability as good as that in Group 1. Thus, we believe that the clinical use of the modified TPLO plate may be advantageous due to greater rigidity than that of a conventional plate, in addition to being minimally invasive.

Compared to the middle third of the bone, the proximal tibia undergoes greater stress in response to torsion forces (Markel et al., 1994). Thus, the modified TPLO plate had a biomechanical advantage because it showed greater stiffness in response to rotation. This advantage becomes even more important with poor bone stock, which limits the number of screws that can be inserted into the proximal fragment. In the present experimental model, the location of the gap permitted insertion of a maximum of 3 screws when using the conventional plate; however, the modified TPLO plate permitted insertion of 5 screws. Although the number of screws was standardized, greater stiffness was obtained with the modified TPLO plate, even without using all the holes.

Rowe-Guthrie et al. (2015) observed that constructs using locked plates and screws located adjacent to the area of failure had higher bending stiffness when compared to constructs in which the locked screws were distant from the failure. Although the screws in Group 1 were not as close to the failure as those in Group 2, the 
difference between the positioning and distribution of the screws between these groups was not sufficient to alter the stiffness of the constructs, as reported by Rowe-Guthrie et al. (2015); however, the authors did not evaluate constructs using torsion force. Thus, use of the modified TPLO plate may be better for proximal tibial fractures than use of the conventional straight plate. The TPLO plate can be applied without approaching the fracture focus, with no biomechanical disadvantage with respect to rigidity, when compared to the conventional implant.

In addition, the possibility of insertion of a greater number of screws in a small area of the plate results in a larger number of plate holes without screws in the fracture focus region. In bridge constructions using minimally invasive plate osteosynthesis, the number of screws/number of holes in the plate should be limited, leaving 2 or 3 holes without screws in the fracture region to avoid concentration of forces in a small area of the implant (Niemeyer and Sudkamp, 2006; Strauss et al., 2008; Cross, 2012).

\section{CONCLUSIONS}

The modified TPLO plate constructs were stiffer than conventional locked plate in torsion. The locked plate presented greater elasticity than the modified TPLO plate, having greater angle at the peak of torque.

\section{REFERENCES}

BORDELON, J.; COKER, D.; PAYTON, M.; ROCHAT, M. An in vitro mechanical comparison of tibial plateau levelling osteotomy plates. Vet. Comp. Orthop. Traumatol., v.22, p.467-472, 2009.

CROSS, A.R. Fracture biology and biomechanics. In: TOBIAS, K.M.; JOHNSTON, S.A. (Eds.). Veterinary surgery: small animal. v.1. St. Louis: Elsevier, Saunders, 2012. p.565571.
HULSE, D. Tibial plate-rod fixation. In BOJRAB, M.J. Current techniques in small animal surgery. 5.ed. Jackson, United States: Teton New Media, 2014. p.797-799.

$\mathrm{KOCH}$, D. Screws and plates. In: JOHNSON, A.L.; HOULTON, J.E.F.; VANNINI, R. (Eds.). AO principles of fracture management in the dog and cat. New York: AO Publishing, 2005. p.2651.

MARKEL, M.D.; SIELMAN, E.; RAPOFF, A.J.; KOHLES, S.S. Mechanical properties of long bones in dogs. Am. J. Vet. Res., v.55, p.1178-1183, 1994

MCKIBBIN, B. The biology of fracture healing in long bones. J. Bone Joint Surg., v.60, p.150162, 1978.

NIEMEYER, P.; SUDKAMP, N.P. Principles and clinical application of the locking compression plate (LCP). Acta Chir. Orthop. Traumatol., v.73, p.221-228, 2006.

POZZI, A.; LEWIS., D.D. Surgical approaches for minimally invasive plate osteosynthesis in dogs. Vet. Comp. Orthop. Traumatol., v.22, p.316-320, 2009.

RONGA, M.; SHANMUGAM, C.; LONGO, U.G.; OLIVA, F.; MAFULLI, N. Minimally invasive osteosynthesis of distal tibial fractures using locking plates. Orthop. Clin. N. Am., v.40, p.499-504, 2009.

ROWE-GUTHRIE, K.M.; MARKEL, M.D.; BLEEDORN, J.A. Mechanical evaluation of locking, nonlocking, and hybrid plating constructs using a locking compression plate in a canine synthetic bone model. Vet. Surg., v.44, p.838-842, 2015.

SLOCUM, B.; SLOCUM, T.D. Tibial plateau leveling osteotomy for repair of cranial cruciate ligament rupture in the canine. Vet. Clin. N. Am. Small Anim. Pract. v.23, p.777-795, 1993.

STRAUSS, E.J.; SCHWARZKOPF, R.; KUMMER, F.; EGOL, K.A. The current status of locked plating: the good, the bad, and the ugly. J. Orthop. Trauma, v.22, p.86-479, 2008. 